\title{
Sensory and Chemical Quality Changes during Storage of Bottle gourd Halwa: Research Article
}

\author{
Suresh Velpula $^{1 *}$, A.G. Bhadania ${ }^{1}$, S. V. Pinto ${ }^{1}$, T. Aravind ${ }^{2}$ and K.S. Umapathy ${ }^{3}$ \\ ${ }^{1}$ Department of Dairy Engineering, S.M.C. College of Dairy Science, AAU, \\ Anand (G.J), India \\ ${ }^{2}$ Department of Dairy Engineering, College of Dairy Science and Food Technology, C.G.K.V., \\ Raipur (C.G), India \\ ${ }^{3}$ Department of Dairy Engineering, College of Dairy Technology, PVNRTVU, Kamareddy, \\ (T.S), India \\ *Corresponding author
}

Keywords

Acidity, Bottle gourd halwa, Free fatty acid, Sensory attributes

Article Info

Accepted:

26 January 2018

Available Online:

10 February 2018

\begin{abstract}
A B S T R A C T
Bottle gourd halwa is a popular khoa based traditional dairy delicacy. It is produced on small scale by local sweetmeat makers. In order to commercially manufacture and market bottle gourd halwa, studies on its shelf-life were considered to be very important. Bottle gourd halwa samples prepared using skim milk powder and khoa as base material were packed in polystyrene packaging material and stored at two different temperature i.e. $7 \pm 2$ ${ }^{\circ} \mathrm{C}$ and $30 \pm 2{ }^{\circ} \mathrm{C}$. Chemical aspects with respect to free fatty acids (FFA) and acidity and sensory changes of bottle gourd halwa such as colour and appearance, body and texture, flavour and overall acceptability were monitored during storage period. The FFA and acidity content in bottle gourd halwa increased significantly $(\mathrm{p}<0.05)$ during storage and these changes were found to be temperature sensitive. Sensory quality of bottle gourd halwa samples found to be gradually decreased significantly $(\mathrm{p}<0.05)$ during storage irrespective of temperature. Bottle gourd halwa samples stored at $7 \pm 2{ }^{\circ} \mathrm{C}$ and $30 \pm 2{ }^{\circ} \mathrm{C}$ were acceptable up to 20 days and 3 days, respectively on the basis of sensory attributes.
\end{abstract}

\section{Introduction}

India is the largest milk producing country in the world and accounting to $19 \%$ of world's total milk production (Keerthi and Kartikeyan, 2017). Conversion of liquid milk into traditional dairy products increases the longevity of milk solids. The consumption of sweets is an integral part of Indian dietary system. Traditional dairy products have great commercial significance as they account for over $90 \%$ of all dairy products consumed in the country (Aneja et al., 2002). About 50$55 \%$ of milk produced is converted into a variety of Indian milk products by the traditional sector (Modha et al., 2015) using processes such as heat desiccation, heat acid coagulation and fermentation, out of which 
about, $5.5 \%$ of total milk production is utilized for khoa making in India (Bandyopadhyay et al., 2006).

In recent years, a lot of interest has been gained in the development of composite food and milk based sweets prepared by combining one or more dairy products with appropriate non-dairy ingredients. These products have higher demand and profit margin (Gaikwad et al., 2015) and having the nutritional value of both milk and non-dairy ingredients such as fruits, vegetables or cereals. Amongst them, khoa based sweets like bottle gourd halwa is very popular.

Bottle gourd (Lagenaria Siceraria Mol. Standley) halwa is a sweet, which is widely popular in North India and many other states. It is traditionally prepared by roasting and cooking of shredded bottle gourd in ghee followed by addition of sugar and khoa with or without edible green colour. Khoa and khoa based sweets, including bottle gourd halwa, have a poor shelf life due to development of rancidity and surface mould growth upon storage. Shelf life studies of any product can provide information to product developers, which make them to ensure good quality product for a significant period of time even after production. The standardized bottle gourd halwa was prepared in the laboratory for characterizing the traditional dairy products of India and generating a valuable database on the chemical and sensory changes of bottle gourd halwa during storage at two different temperature i.e. $7 \pm 2{ }^{\circ} \mathrm{C}$ and $37 \pm 2{ }^{\circ} \mathrm{C}$.

\section{Materials and Methods}

The work was carried out at Department of Dairy Engineering of Sheth M. C. College of Dairy Science, Anand Agricultural University (G.J.). "SAGAR" brand skim milk powder manufactured by AmulFed Dairy (Mother Dairy, Gandhinagar) was procured from the local market of Anand, Gujarat. Fresh khoa and ghee were procured from the Department of Dairy Processing Operations (Anubhav Dairy), Sheth M. C. College of Dairy Science, Anand Agricultural University, Anand. A white fine crystalline sugar (sucrose) of commercial grade, good quality green cardamom and apple green color of food grade quality were obtained from the local market of Anand, Gujarat. Specially designed horizontal scraped surface heat exchanger was used for manufacturing of bottle gourd halwa using skim milk powder as a base material instead of khoa.

\section{Preparation of bottle gourd halwa in horizontal SSHE}

Initially LPG fuel supply for gas burner was started to get the desirable steam pressure in water jacket of the SSHE. When it reaches to operating pressure, ghee @ 7 per cent (w/w) of shredded bottle gourd was taken in clean and dry SSHE and scraper assembly was started. On heating the ghee, shredded bottle gourd was added in the SSHE through feed hopper. As heating continue, cooking of shredded bottle gourd takes place. Cooking of shredded bottle gourd was judged by intermittently stopping the machine. When shredded bottle gourd was cooked properly, sugar @ 30 per cent $(w / w)$ of shredded material was added in the machine.

After 5-6 min of time interval 50 percent TS reconstituted skim milk (SMP @ 20 per cent w/w of shredded material) was added. The process of evaporation and concentration continued during this operation until it reaches to desired lump formation stage. Finally permitted food grade apple green colour was added at this stage to impart little greenish appearance of the product. Then LPG supply was put off and the product was removed from the SSHE and transferred to greased (with ghee) stainless steel plate, cardamom was 
added before spreading evenly. Control product (bottle gourd halwa using khoa) was prepared according to the method reported by Aneja et al., (2002). Samples were then packed in polystyrene packaging material.

\section{Storage and analysis of bottle gourd halwa}

The samples of bottle gourd halwa were stored in polystyrene packaging material at two temperature i.e. $7 \pm 2{ }^{\circ} \mathrm{C}$ and $30 \pm 2{ }^{\circ} \mathrm{C}$. The samples stored at $7 \pm 2{ }^{\circ} \mathrm{C}$ and $30 \pm 2{ }^{\circ} \mathrm{C}$ were analyzed at $5 \mathrm{~d}$ and $1 \mathrm{~d}$ interval of storage for sensory and chemical changes.

\section{Sensory evaluation}

The sensory attributes of bottle gourd halwa were analyzed for colour and appearance, flavour, body and texture and overall acceptability by a trained panel of judges consisting of six members by using a nine point hedonic scale $(1=$ dislike extremely; $9=$ like extremely).

The samples of products stored at refrigeration temperature were tempered at room temperature for $1-2 \mathrm{~h}$ before judging. The samples were coded for judging and the criticism expressed by common agreement of the judges was recorded. Stored products were rejected on sensory basis as well as visible yeast and mould growth.

\section{Chemical analysis}

The samples of bottle gourd halwa were evaluated for FFA and titratable acidity during storage at $7 \pm 2{ }^{\circ} \mathrm{C}$ and $30 \pm 2{ }^{\circ} \mathrm{C}$ temperature. The method prescribed by Deeth et al., (1975) was used to estimate the FFA content of bottle gourd halwa.

Titratable acidity was determined by procedure described as per BIS Handbook, BIS: Part XI, 1981.

\section{Results and Discussion}

Chemical changes in bottle gourd halwa during storage

\section{Effect of storage period on FFA content of bottle gourd halwa}

The FFA content of control and experimental bottle gourd halwa samples stored at $7 \pm 2{ }^{\circ} \mathrm{C}$ and $30 \pm 2{ }^{\circ} \mathrm{C}$ is shown in Fig. 1a and Fig. 1b respectively. The FFA content of both bottle gourd halwa samples increased significantly $(p<0.05)$ with the progression of storage period. A gradual increase of fatty acids in bottle gourd halwa samples was noticed during storage. The rate of increase in FFA was maximum in bottle gourd halwa samples stored at $30 \pm 2{ }^{\circ} \mathrm{C}$, wherein free fatty acids of control and experimental samples increased from initial value of $0.07,0.06$ on the first day to $0.269,0.264 \%$ oleic acid after storage period of $3 \mathrm{~d}$, respectively (Fig. 1a). The FFA content of fresh control and experimental bottle gourd halwa samples increased to $0.152,0.148 \%$ oleic acid on $20 \mathrm{~d}$ during storage at $7 \pm 2{ }^{\circ} \mathrm{C}$ (Fig. 1b). It was noted that rate of increase in FFA content was slower in bottle gourd halwa samples stored at $7 \pm 2{ }^{\circ} \mathrm{C}$ as compared to bottle gourd halwa samples stored at $30 \pm 2{ }^{\circ} \mathrm{C}$. The release of free fat during the preparation of bottle gourd halwa and presence of high moisture content could be responsible for lipolysis during storage, the rate of which is expected to be higher at higher temperature of storage. Kumar et al., (2010) in khoa, Yadav and Beniwal (2009), Jha et al., (1977) and Vijaykhader and Patel (1983) in peda also found a significant increase in free fatty acids with storage time.

\section{Effect of storage period on titratable acidity of bottle gourd halwa}

The titrable acidity (expressed as percent lactic acid) is an important chemical change, 
changes in acidity may even influence the consumer's acceptability of the product too. The acidity of control and experimental bottle gourd halwa samples stored at $7 \pm 2{ }^{\circ} \mathrm{C}$ and $30 \pm 2{ }^{\circ} \mathrm{C}$ is graphically represented in Fig. 2a and Fig. 2b respectively. Acidity content of bottle gourd halwa increased gradually with the storage period at $7 \pm 2{ }^{\circ} \mathrm{C}$ and $30 \pm 2{ }^{\circ} \mathrm{C}$. It showed the significant difference $(\mathrm{p}<0.05)$ in acidity content on storage. The acidity of bottle gourd halwa samples stored at $30 \pm 2{ }^{\circ} \mathrm{C}$ increased consistently with the increase in storage period as compared to bottle gourd halwa samples stored at $7 \pm 2{ }^{\circ} \mathrm{C}$. On the initial day of storage, the acidity content of bottle gourd halwa stored at $30 \pm 2{ }^{\circ} \mathrm{C}$ and $7 \pm 2{ }^{\circ} \mathrm{C}$ were $0.342,0.350$ for control and experimental samples, which increased to $0.430,0.436$ and $0.393,0.398$ during storage after $3 \mathrm{~d}$ and $20 \mathrm{~d}$, respectively. Despite the gradual increase in acidity none of the samples tasted sour and the acidity levels were within the acceptable limits. The acidity development could be attributed to production of acids like formic acid, acetic acid, lactic acids and other organic acids and FFA as reported by O'Brien (1997). Similar findings were reported by Kalra et al., (1983) in khoa and Sachdeva and Rajorhia (1982) in burfi during storage. Thus the results obtained in the present investigations corroborate with those reported in the literature.

\section{Changes in sensory attributes of bottle gourd halwa during storage}

\section{Effect of storage period on flavour scores of bottle gourd halwa}

The flavour of any food product including bottle gourd halwa is most important sensory attribute, as far as consumer like is concerned because it determines its acceptance or rejection. The flavour scores of control and experimental bottle gourd halwa samples stored at $30 \pm 2{ }^{\circ} \mathrm{C}$ and $7 \pm 2{ }^{\circ} \mathrm{C}$ are shown in
Table 1 and Table 2, respectively. Flavour scores of bottle gourd halwa, decreased continuously during the storage period irrespective of temperature. During storage of bottle gourd halwa at $30 \pm 2{ }^{\circ} \mathrm{C}$, flavour score up to $3 \mathrm{~d}$ was observed and thereafter the product became unacceptable due to visible mould growth. It can be seen that the flavour score decreased rapidly at $30 \pm 2{ }^{\circ} \mathrm{C}$ as compared to $7 \pm 2{ }^{\circ} \mathrm{C}$ during storage. The decrease in flavour score could be attributed to slight loss of freshness, which is inherent in any food product. In fresh product, the compounds formed during browning reactions are responsible for the typical flavour of the product, but as storage period progresses, the chemical reactions disturbed the delicate balance of the compounds. The findings of the present study are in accordance with the result reported by Chawla et al., (2013) in doda burfi, Londhe et al., (2012), Jha et al., (2012) and Biradar et al., (1985) for brown peda, Rao and Goyal (2007) in kalakand and Sharma et al., (2003) in malai peda samples during storage study.

Effect of storage period on colour and appearance scores of bottle gourd halwa

The colour and appearance of the product is important for the consumer appeal. The bottle gourd halwa samples showed significant $(\mathrm{p}<0.05)$ decrease in colour and appearance scores at $30 \pm 2{ }^{\circ} \mathrm{C}$ and $7 \pm 2{ }^{\circ} \mathrm{C}$ during storage as shown in Table 1 and Table 2, respectively. The score ranged between 8.54-6.94 and 8.386.88 during storage at $30 \pm 2{ }^{\circ} \mathrm{C}$ for control and experimental bottle gourd halwa, respectively. At the end of $20 \mathrm{~d}$ score was decreased to 7.11, 7.06 for control and experimental samples during storage at $7 \pm 2{ }^{\circ} \mathrm{C}$. During storage, the samples became drier in appearance and lacked the greasy appearance desired in good quality bottle gourd halwa, which resulted in a steady decrease in colour and appearance scores. 
Table.1 Sensory scores of control and experimental bottle gourd halwa during storage at $30 \pm 2{ }^{\circ} \mathrm{C}$

\begin{tabular}{|c|c|c|c|c|c|c|c|c|}
\hline \multirow{2}{*}{$\begin{array}{l}\text { Periods ( } P \text { in } \\
\text { days) }\end{array}$} & \multicolumn{2}{|c|}{ Flavour scores } & \multicolumn{2}{|c|}{ Body and Texture scores } & \multicolumn{2}{|c|}{ Colour and Appearance scores } & \multicolumn{2}{|c|}{ Overall Acceptability scores } \\
\hline & Control & Experimental & Control & Experimental & Control & Experimental & Control & Experimental \\
\hline $\mathbf{0}$ & $8.45 \pm 0.26$ & $8.26 \pm 0.21$ & $8.47 \pm 0.23$ & $8.41 \pm 0.24$ & $8.54 \pm 0.20$ & $8.38 \pm 0.21$ & $8.51 \pm 0.24$ & $8.39 \pm 0.25$ \\
\hline 1 & $8.32 \pm 0.25$ & $8.15 \pm 0.27$ & $8.31 \pm 0.26$ & $8.29 \pm 0.23$ & $8.46 \pm 0.18$ & $8.24 \pm 0.20$ & $8.36 \pm 0.31$ & $8.22 \pm 0.27$ \\
\hline 2 & $7.65 \pm 0.31$ & $7.61 \pm 0.28$ & $7.80 \pm 0.18$ & $7.78 \pm 0.20$ & $7.51 \pm 0.26$ & $7.45 \pm 0.24$ & $7.58 \pm 0.26$ & $7.51 \pm 0.24$ \\
\hline \multirow[t]{2}{*}{3} & $6.76 \pm 0.21$ & $6.71 \pm 0.23$ & $7.12 \pm 0.28$ & $7.07 \pm 0.27$ & $6.94 \pm 0.23$ & $6.88 \pm 0.27$ & $6.84 \pm 0.21$ & $6.81 \pm 0.23$ \\
\hline & SEm \pm & CD at $5 \%$ & SEm \pm & CD at $5 \%$ & SEm \pm & CD at $5 \%$ & SEm \pm & CD at $5 \%$ \\
\hline P (Periods) & 0.104 & 0.314 & 0.097 & 0.294 & 0.093 & 0.280 & 0.103 & 0.312 \\
\hline T (Treatment) & 0.073 & NS & 0.069 & NS & 0.065 & NS & 0.073 & NS \\
\hline $\mathbf{P}^{*} \mathbf{T}$ & 0.147 & NS & 0.138 & NS & 0.131 & NS & 0.146 & NS \\
\hline
\end{tabular}

Each observation is a mean \pm SD of three replicate experiments $(n=3)$; NS=Non significant at $5 \%$ level of significance

Table. 2 Sensory scores of control and experimental bottle gourd halwa during storage at $7 \pm 2{ }^{\circ} \mathrm{C}$

\begin{tabular}{|c|c|c|c|c|c|c|c|c|}
\hline \multirow{2}{*}{$\begin{array}{l}\text { Periods ( } P \text { in } \\
\text { days) }\end{array}$} & \multicolumn{2}{|c|}{ Flavour scores } & \multicolumn{2}{|c|}{ Body and Texture scores } & \multicolumn{2}{|c|}{ Colour and Appearance scores } & \multicolumn{2}{|c|}{ Overall Acceptability scores } \\
\hline & Control & Experimental & Control & Experimental & Control & Experimental & Control & Experimental \\
\hline $\mathbf{0}$ & $8.45 \pm 0.26$ & $8.26 \pm 0.21$ & $8.47 \pm 0.23$ & $8.41 \pm 0.24$ & $8.54 \pm 0.20$ & $8.38 \pm 0.21$ & $8.51 \pm 0.24$ & $8.39 \pm 0.25$ \\
\hline 5 & $8.25 \pm 0.23$ & $8.05 \pm 0.25$ & $8.30 \pm 0.32$ & $8.26 \pm 0.25$ & $8.41 \pm 0.22$ & $8.22 \pm 0.26$ & $8.32 \pm 0.24$ & $8.18 \pm 0.26$ \\
\hline 10 & $7.53 \pm 0.27$ & $7.47 \pm 0.22$ & $7.92 \pm 0.21$ & $7.89 \pm 0.26$ & $7.95 \pm 0.28$ & $7.87 \pm 0.25$ & $7.56 \pm 0.21$ & $7.45 \pm 0.21$ \\
\hline 15 & $7.09 \pm 0.20$ & $7.01 \pm 0.19$ & $7.67 \pm 0.27$ & $7.60 \pm 0.22$ & $7.30 \pm 0.21$ & $7.27 \pm 0.18$ & $7.17 \pm 0.27$ & $7.12 \pm 0.29$ \\
\hline \multirow[t]{2}{*}{20} & $6.85 \pm 0.24$ & $6.81 \pm 0.25$ & $7.27 \pm 0.19$ & $7.22 \pm 0.23$ & $7.11 \pm 0.29$ & $7.06 \pm 0.25$ & $6.87 \pm 0.22$ & $6.83 \pm 0.25$ \\
\hline & SEm \pm & CD at $5 \%$ & SEm \pm & CD at $5 \%$ & SEm \pm & CD at $5 \%$ & SEm \pm & CD at $5 \%$ \\
\hline P (Periods) & 0.095 & 0.283 & 0.100 & 0.296 & 0.097 & 0.289 & 0.100 & 0.297 \\
\hline T (Treatment) & 0.060 & NS & 0.063 & NS & 0.062 & NS & 0.063 & NS \\
\hline $\mathbf{P} * \mathbf{T}$ & 0.135 & NS & 0.141 & NS & 0.138 & NS & 0.142 & NS \\
\hline
\end{tabular}

Each observation is a mean \pm SD of three replicate experiments $(n=3)$; NS=Non significant at $5 \%$ level of significance 
Fig.1a FFA content of control and experimental bottle gourd halwa stored at $30 \pm 2{ }^{\circ} \mathrm{C}$

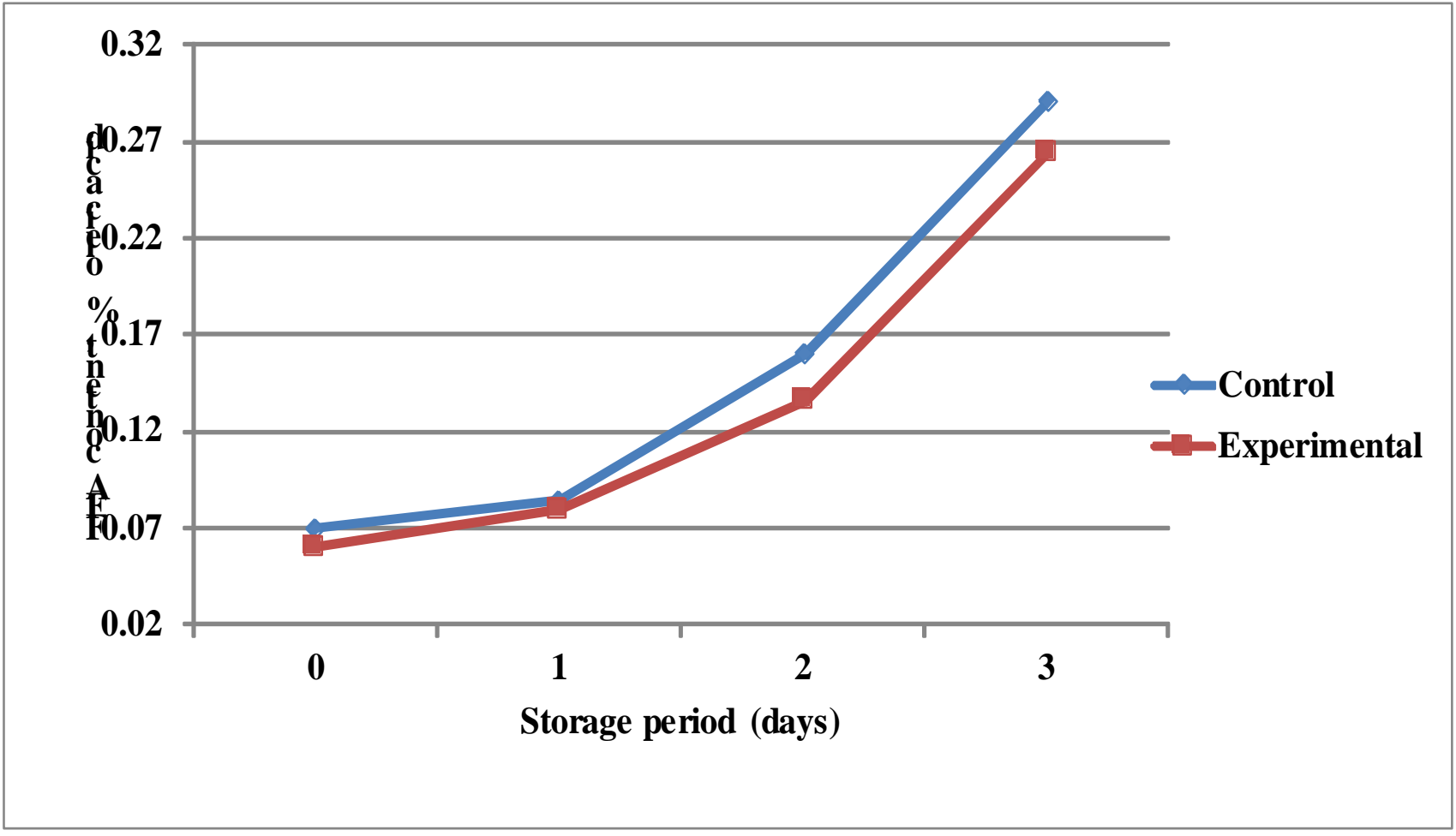

Fig.1b FFA content of control and experimental bottle gourd halwa stored at $7 \pm 2{ }^{\circ} \mathrm{C}$

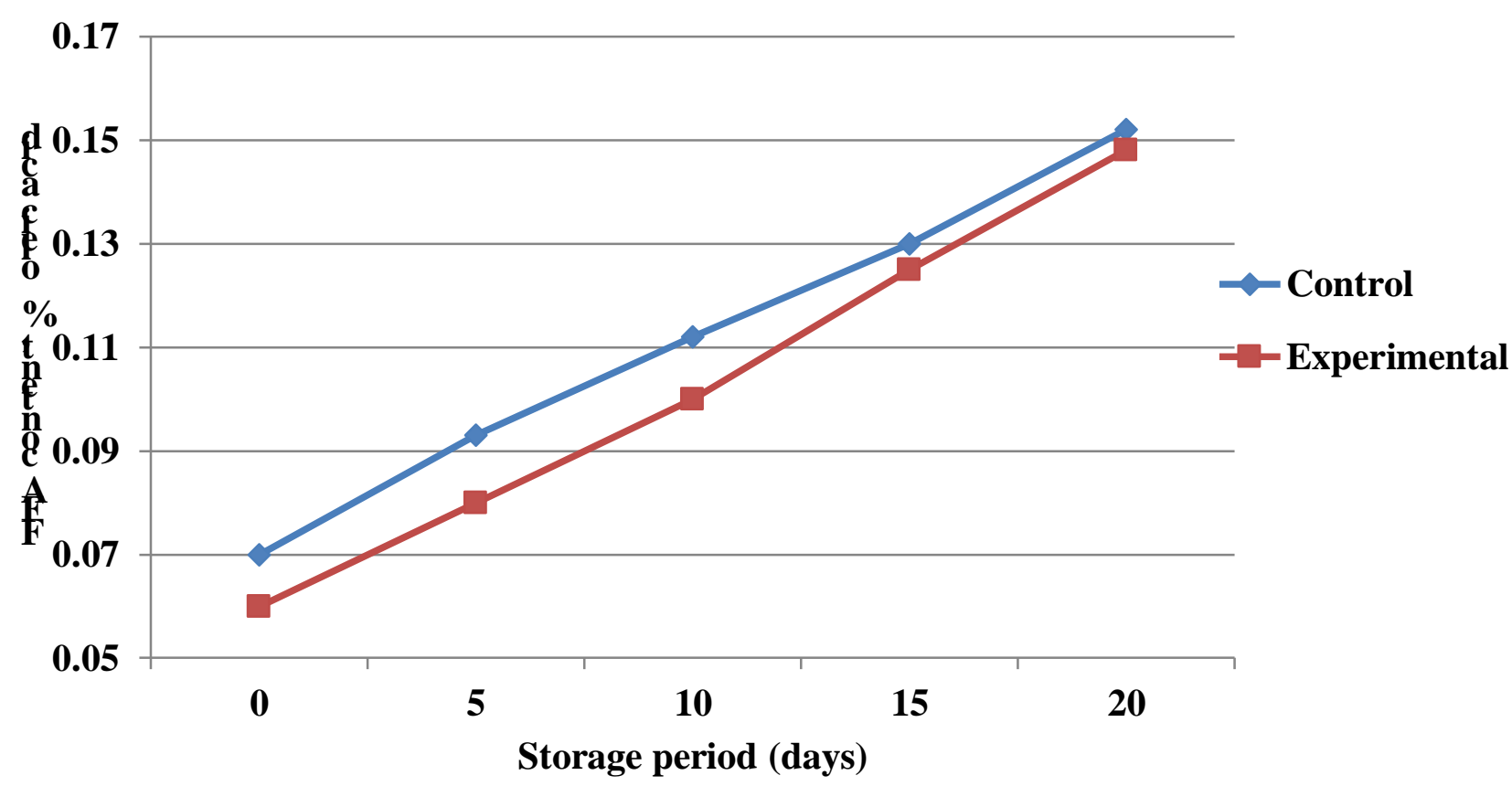


Fig.2a Acidity of control and experimental bottle gourd halwa stored at $30 \pm 2{ }^{\circ} \mathrm{C}$

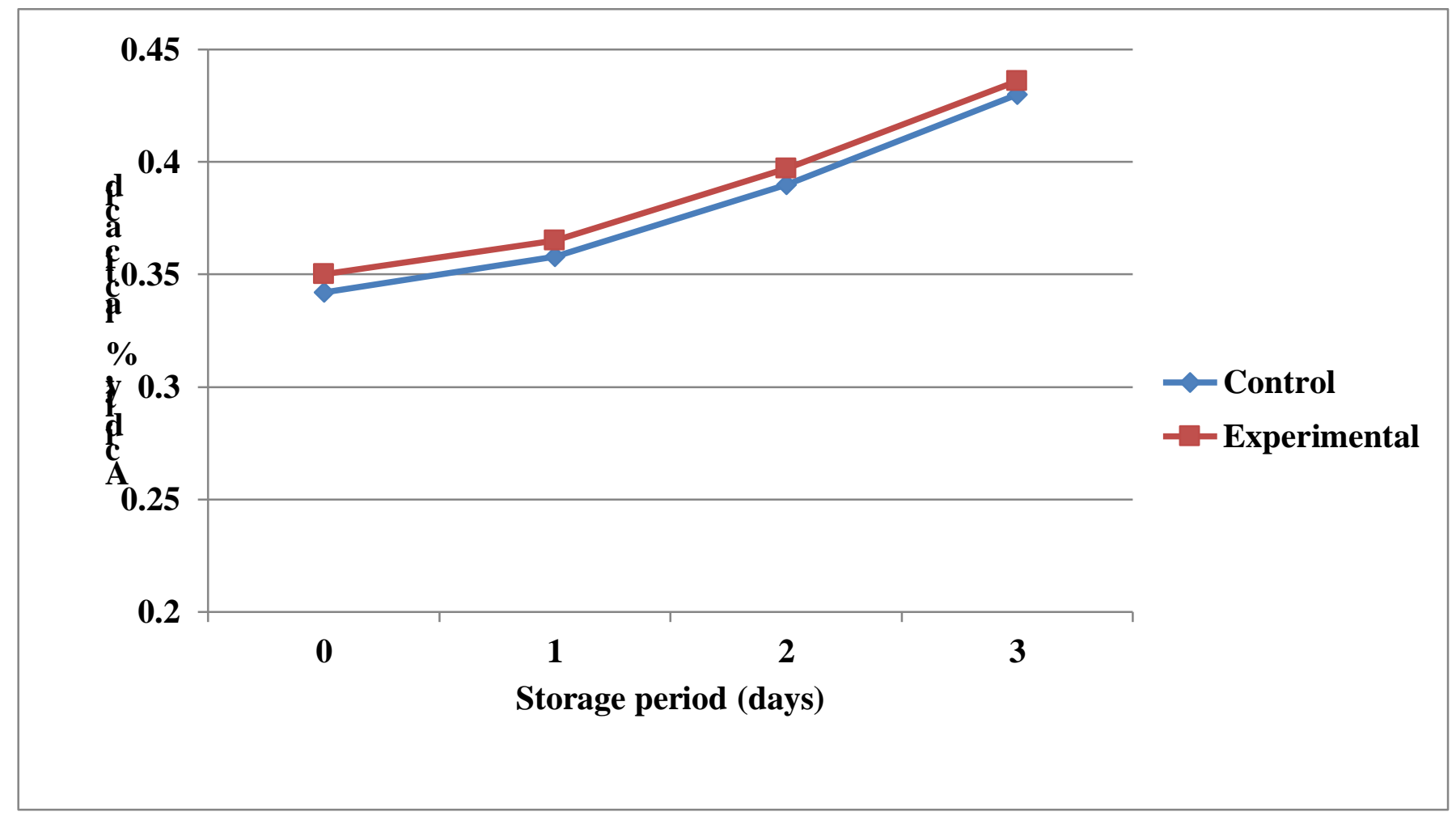

Fig.2b Acidity content of control and experimental bottle gourd halwa stored at $7 \pm 2{ }^{\circ} \mathrm{C}$

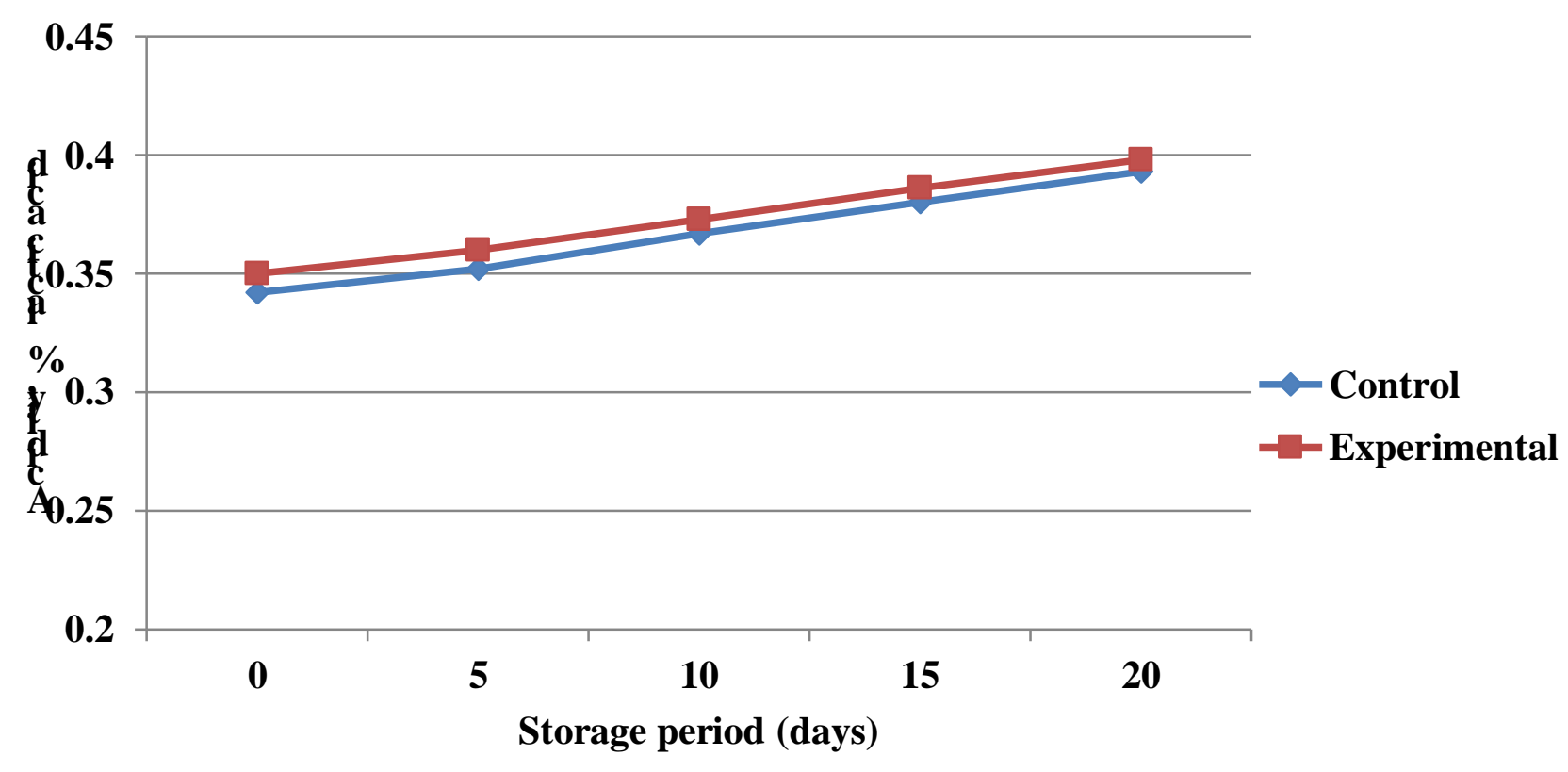


These results are in accordance with those observed by Chawla et al., (2013) in doda burfi, Londhe et al., (2012) and Jha et al., (2012) in lal peda who also noted a decrease in colour and appearance scores during storage study.

\section{Effect of storage period on body and texture scores of bottle gourd halwa}

Body and texture is an important sensory attribute of bottle gourd halwa. The body and texture of the product helps in its marketing value. It also shows product's inner makeup. The influence of storage period on body and texture scores of control and experimental bottle gourd halwa samples stored at $30 \pm 2{ }^{\circ} \mathrm{C}$ and $7 \pm 2$ ${ }^{\circ} \mathrm{C}$ is presented in Table 1 and Table 2, respectively. Body and texture score of gourd halwa stored at $7 \pm 2{ }^{\circ} \mathrm{C}$ was found to be acceptable up to $20 \mathrm{~d}$ as compared with $3 \mathrm{~d}$ for bottle gourd halwa stored at $30 \pm 2{ }^{\circ} \mathrm{C}$. The statistical analysis indicates that effect of storage temperature had significant effect $(p<0.05)$ on body and texture scores of bottle gourd halwa samples. A similar decrease in body and texture scores was observed in multigrain halwa samples kept at $30 \pm 2{ }^{\circ} \mathrm{C}$ and $7 \pm 2{ }^{\circ} \mathrm{C}$ of storage (Itagi et al., 2011). Jha et al., (2012) reported that the body and texture score of lal peda decreased during storage.

\section{Effect of storage period on overall} acceptability scores of bottle gourd halwa

The overall acceptability score is the sum of all sensory attributes scores given by the judges while evaluating the product. The effect of storage period at $30 \pm 2{ }^{\circ} \mathrm{C}$ and $7 \pm 2{ }^{\circ} \mathrm{C}$ on overall acceptability scores of control and experimental bottle gourd halwa is shown in Table 1 and Table 2, respectively. There was a significant $(p<0.05)$ effect of storage temperature on the overall acceptability scores. The overall acceptability scores of bottle gourd halwa, decreased with progressive period of storage at both the temperatures. The influence of storage period and temperature of storage was significant $(p<0.05)$ for changes in flavour, colour and appearance and body and texture and thus, overall acceptability scores. Jha et al., (2012) also resulted that overall acceptability was significant $(\mathrm{p}<0.01)$ effect on storage temperature and it was decreased during period of storage at $37 \pm 2{ }^{\circ} \mathrm{C}$. It was observed that there was no difference in shelf life of control and experimental bottle gourd halwa.

The type of treatment and interaction between treatment and storage period was found to be non-significant for all sensory and chemical characters.

The present study was planned systematically to characterize and delineate the sensory and chemical changes of bottle gourd halwa during storage. This study showed that temperature of storage and storage period significantly $(p<0.05)$ affects the sensory and chemical attributes of bottle gourd halwa. The shelf life of bottle gourd halwa prepared in horizontal SSHE using SMP as one of the ingredients and packed in metal coated polystyrene was at par ( $>0.05$ ) with the control product prepared using khoa. Bottle gourd halwa samples stored at $7 \pm 2{ }^{\circ} \mathrm{C}$ were sensorial acceptable up to $20 \mathrm{~d}$. However, samples stored at $30 \pm 2{ }^{\circ} \mathrm{C}$, could not be stored for more than $3 \mathrm{~d}$ in view of fast deteriorative changes. The changes in acidity and FFA content of experimental and control products during storage at $30 \pm 2{ }^{\circ} \mathrm{C}$ and $7 \pm 2{ }^{\circ} \mathrm{C}$ were significantly $(\mathrm{p}<0.05)$ increased. Low temperature always promotes a longer shelf life of many products and the same was confirmed in this study. This could be attributed to the lower rate of lipid oxidation and non-enzymatic browning reactions which decreases the shelf life of products stored at elevated temperatures. This study is useful from the point of view of the need to undertake concerted efforts in characterizing and enhancing the shelf-life of traditional dairy products of India.

\section{References}

Aneja, R.P., Mathur, B.N., Chauhan, R.C., and Banerjee, A.K. 2002. Technology of Indian dairy products. Pp. 122-204.

Bandyopadhyay, M., Mukherjee, R.S., 
Chakraborty, R., and Raychaudhuri, U. 2006. A survey on formulations and process techniques of some special Indian traditional sweets and herbal sweets. Indian Dairyman. 58, 23-35.

Biradar, U.S., Dev, D.K., and Ingle, U.M. 1985. Shelf life extension of pedha by packaging. J. Food Sci., 50(1), 51-55.

Bureau of Indian Standards Handbook (BIS: Part XI). 1981. Handbook of food analysis, dairy products. Indian Standards Institution, ManakBhavan, New Delhi.

Chawla, R., Patil, G.R., and Singh, A.K. 2013. Effect of temperature on sensory and textural attributes of functional doda burfi (Indian milk cake). J. Food Sci. Technol., DOI 10.1007/s13197-013-1027-6.

Deeth, H.C., Fitz-Gerald, C.H., and Wood, A.F. 1975. A convenient method for determining the extent of lipolysis in milk. Aust J Dairy Tech., 30, 109-111.

Gaikwad, S.M., Hembade, A.S., Landge, S.N., and Chate, B.N. 2015. Comparative Study of physicochemical and sensorial properties of Indian desiccated dairy product ujani basundi and basundi. International Journal of Current Microbiology and Applied Sciences. 4, 164-167.

Itagi, H.N., Singh, V., Indiramma, A.R., and Prakash, M. 2011. Shelf stable multigrain halwa mixes: preparation of halwa, their textural and sensory effect. J Food Sci. Technol., DOI: 10.1007/s13197-011-0423$\mathrm{z}$.

Jha, A., Kumar, A., Jain, P., Om, H., Singh, R., and Bunkar, D.S. 2012. Physical-Chemical and sensory changes during storage of lal peda. J Food Sci. Technol., 63(5), 17-19.

Jha, Y.K., Singh, S., Singh, S. 1977. Effect of antioxidants and antimicrobial substances on keeping quality of khoa. Indian J. Dairy Sci., 30, 1-6.

Kalra, M.S., Laxminarayan, H., and Dudani, D. 1973. Use of nisin for extending shelf-life of processed cheese and khoa. J. Food Sci Technol., 10, 92-94.

Keerthi, S., and Kartikeyan, S. 2017. Effect of aloe vera juice incorporation on texural and sensory characteristics of the peda during storage at $37 \pm 1{ }^{\circ} \mathrm{C}$. International journal of food and nutritional science. 6(3), 108-118.

Kumar, M., Beniwal, B.S., and Rai, D.C. 2010. Effect of antioxidant on shelf life of khoa under refrigerated conditions. Egypt J Dairy Sci., 38, 211-218.

Londhe, G., Pal, D. and Raju, P. 2012. Effect of packaging techniques on shelf life of brown peda, a milk based confection. J Food Sci and Technol., 47(1), 117-125.

Modha, H.M., Patel, N.M., Patel, H.G., and Patel, K.N. 2015. Process standardization for the manufacture of thabdi peda. J Food Sci and Technol., 52, 3283-3290.

O' Brien, J. 1997. Reaction chemistry of lactose: non-enzymatic degradation pathways and their significance in dairy products. In: Fox PF (Ed) Advanced Dairy Chemistry, Vol. 3. Chapman \& Hall, Madras, Pp. 248.

Rao, R.S., and Goyal, G.K. 2007. Effect of packaging and storage on the sensory quality of kalakand. Indian J. Dairy Sci., 60(2), 77-80.

Sachdeva, S., and Rajorhia, G.S. 1982. Studies on the technology and shelf life of burfi. Indian J. Dairy Sci., 35, 513-516.

Sharma, H.K., Singhal, R.S., and Kulkarni, P.R. 2003. Effect of modified atmosphere packaging on the keeping quality of malai peda. J Food Sci Technol., 40(5), 543-545.

Vijaykhder, and Patel, Y.K. 1983. Composition and packaging of peda. Indian J. Dairy Sci., 36, 187.

Yadav, R., Beniwal, B.S. 2009. Effect of antioxidants and preservatives on keeping quality of peda stored at sub-zero temperature. J Dairy Foods Home Sci., 28, 164-169.

\section{How to cite this article:}

Suresh Velpula, A.G. Bhadania, S.V. Pinto, T. Aravind and Umapathy, K.S. 2018. Sensory and Chemical Quality Changes during Storage of Bottle gourd Halwa: Research Article. Int.J.Curr.Microbiol.App.Sci. 7(02): 3302-3310. doi: https://doi.org/10.20546/ijcmas.2018.701.393 